\title{
14
}

\section{Exploring Impacts of Land Use Change on Sediment Erosion in the Cayuga Creek Watershed, Niagara Falls, New York, using BASINS SWAT}

\author{
Joseph J. Gould, Kim N. Irvine, Mary F. Perrelli and Kimly Reth
}

In Niagara County, nutrient and toxic substance loads associated with sediment erosion and surface runoff from agricultural and urban land uses were listed as major countywide concerns (Niagara County Water Quality Committee, 1992). The focus area of this study was the Cayuga Creek watershed, located in Niagara County, New York. This is considered a mixed land use watershed but it predominantly consists of agricultural land with interspersed residential areas and an urban center at the confluence of Cayuga Creek and the Niagara River. The Cayuga Creek watershed has the same water quality issues as Niagara County, but as a result of the watershed's land use further emphasis must be placed on sediment erosion and nonpoint source (NPS) pollution from agricultural land use.

The United States Environmental Protection Agency (USEPA) addresses sediment erosion and NPS pollution issues collectively in Section 303(d) of the Clean Water Act, which requires individual states to implement a total maximum daily load (TMDL) plan (Santhi et al., 2001; Santhi et al., 2006). A TMDL plan establishes the load capacity of a water body, as well as the sources and amounts of pollutants that have to be reduced to meet water quality standards. After a TMDL plan is established, often best management practices

Gould, J., K. Irvine, M. Perrelli and K. Reth. 2010. "Exploring Impacts of Land Use Change on Sediment Erosion in the Cayuga Creek Watershed, Niagara Falls, New York, using BASINS SWAT." Journal of Water Management Modeling R236-14. doi: 10.14796/JWMM.R236-14.

(C) CHI 2010 www.chijournal.org ISSN: 2292-6062 (Formerly in Dynamic Modeling of Urban Water Systems. ISBN: 978-0-9808853-3-0) 
(BMPs) are used to reduce sediment erosion and NPS pollution associated with surface runoff (Bracmort et al., 2006).

Watershed modeling can be used to assist in the implementation and evaluation of BMP scenarios by allowing for a better understanding of the relationship between land use, land management activities, and water quality processes occurring within a watershed (Im et al., 2003). The amended Water Resources Development Act of 1996, Section 516(e), gives state and local officials the authority to evaluate and implement such water resource conservation projects. The USEPA recommends that state and local officials use a suite of models available in the Better Assessment Science Integrating Point and Nonpoint Sources (BASINS) framework to assess water resource conservation projects. The soil and water assessment tool (SWAT) has been used in national studies as well as regional 516(e) studies to asses BMPs and TMDL plans, and is one of the models included in BASINS (Di Luzio et al. 2002).

In the specific case of Cayuga Creek, early coordination with stakeholders making up the Cayuga Creek Watershed Management Committee (including Buffalo Niagara Riverkeeper, USDA Natural Resources Conservation Service, US Army Corps of Engineers, Buffalo District, U.S. Fish and Wildlife Service, New York State Department of Environmental Conservation, Niagara County Soil and Water Conservation District [NCSWCD], Town of Niagara, Town of Lewiston, Council of Chiefs, The Tuscarora Nation, Buffalo State College, Cornell Cooperative Extension, and Niagara University) was made in an effort to ensure that the sediment transport model better reflected stakeholder expectations for the application of BMPs in the watershed.

In particular, it was noted by Buffalo Niagara Riverkeeper that they would like a tool or tools by which they could assess impact from change in land use. BASINS SWAT was selected for use in this project because it has been used for work in other local watersheds (e.g. Inamdar and Naumov, 2006), and personnel at the NCSWCD office have some experience with BASINS SWAT applications for the 18-Mile Creek watershed. The SWAT model is also being used for a 516(e) study of the Cuyahoga River, Ohio, and as such there will be some consistency across multiple 516(e) projects.

The SWAT model calibration and validation procedures were done using flow, turbidity and total suspended solids (TSS) data collected at two sites in Cayuga Creek. Rating curves between flow and depth and between TSS and turbidity were established, which will also assist in future data collection efforts. The establishment of such procedures is pertinent because past collection efforts of TSS and flow data within the watershed have been scarce (URS Corporation and Gomez and Sullivan, 2005). Furthermore, the model will serve as 
a basis to build upon, as well as a framework to catalog future water quality data that can be used for a more accurate model calibration.

Land use-land cover (LULC) maps for 2005 and 1958 were developed for the watershed as part of the development of the SWAT model. These LULCs will aid state and local agencies in assessing present and historical distribution of land use, as a first step in assessing how changing land use might impact water quality.

\subsection{SWAT Model}

\subsubsection{Model Description and Usefulness}

The SWAT model is a physically based model that was developed by the United States Department of Agriculture-Agriculture Research Service, and has integrated this agency's modeling experience from the past 30 years (Santhi et al., 2006; Gassman et al., 2007).

SWAT is designed to model and predict impacts to hydrology, sediment, and water quality as a result of management practices in a watershed (Im et al., 2003) and has been applied to watersheds worldwide (Gassman et al., 2007). The model is designed to operate on a daily or monthly time step for long periods, which is effective when assessing land management practices (Arnold et al., 1998; Bracmort et al., 2006; Im et al., 2003; Santhi et al., 2006). For example, Santhi et al. (2006) used this model to assess water quality management programs because of its ability to model continuous land use processes in a large watershed by dividing the watershed into subbasins, allowing for a detailed level of spatial variability. Grunwald and Qi (2006) looked at sediment and nutrient discharges to the Ohio section of Lake Erie using SWAT. Larose et al. (2007) used SWAT to examine pesticide dynamics in a watershed in Indiana.

A number of reports indicate that SWAT was developed, in particular, to help make management decisions for large, ungauged watersheds (e.g. Santhi et al., 2006; Gassman et al., 2007) and given the limited flow and sediment data available for the Cayuga Creek watershed, this model focus was attractive. Because SWAT has an open source code, there have been a number of adaptations over the years to provide improved simulation of specific processes. Various GIS and other interface tools to support the input of topographic, land use, soil, and other digital data into SWAT also have been developed (Di Luzio et al. 2002; Gassman et al., 2007).

An important aspect of SWAT that has facilitated its application to many 
different types and sizes of watersheds is its use of nonspatial hydrologic response units (HRUs) in generating subbasin flow and pollutant routing (Gassman et al., 2007).

Accurate representation of the rainfall-runoff process has long been the goal of hydrologists. With increasing computing power over the past 20 years it has been possible to better represent the spatial variability of the rainfall-runoff process. In any catchment there may be many points that act in a hydrologically similar way with a similar water balance and similar runoff generation (Flugel, 1995; Bevan, 2004). As such, the concept of HRUs was developed in which HRUs are parcels of the landscape differentiated by overlaying maps of different characteristics (soils, slope, vegetation). Similar HRUs within the catchment will often be grouped together into a single unit for calculation purposes. Within a single catchment or subbasin it is possible to have several HRUs.

SWAT provides the option of defining HRUs through soils and land use layers in a couple of different ways. A single HRU or multiple HRUs may be assigned to each subbasin. If a single HRU per subbasin is set, the HRU is determined by dominant land use category and soil type within the watershed. The multiple HRUs option allows the setting of sensitivities for the land use and soil data that will be used to determine the number and types of HRUs in each subbasin. With the multiple HRUs per subbasin option, land use and soil threshold levels may be set to eliminate the minor land use and soil in each subbasin.

There is no specific criterion for setting the threshold value for land use and soil, but for most projects, the default threshold values are set as $20 \%$ for land use and 10\% for soil (USEPA, 2001). Once the threshold values are set, the land uses and soil that cover a percentage of the subbasin area less than the threshold levels are eliminated. After the elimination process, the areas of the remaining land use and soil are reapportioned in order to maintain $100 \%$ of land area in the subbasin to be modeled.

This HRU approach becomes both a strength and weakness of the model since it keeps the model fairly simple for widespread use, but the impact of pollutant losses are treated identically from all landscape positions within a subbasin, and attenuation between the source area and a stream is ignored. Explicit spatial representation of BMPs (e.g. riparian buffer zones, targeted placement of land use) therefore is not possible within a subbasin (Gassman et al., 2007).

\subsubsection{Model Components}

SWAT has eight major subsections: hydrology, erosion and sedimentation, 
weather, plant growth, pesticides, nutrients, soil temperature, and land management (Arnold et al., 1998). The water budget component of the model is representative of the following storage volume layers: snow (when present), canopy storage, soil profile, shallow aquifer, and deep aquifer. The soil profile layer can be further characterized by the hydrologic processes occurring, including: evaporation, plant uptake, lateral flow, infiltration, and percolation to deeper layers (Lenhart et al., 2002; Santhi et al., 2001; Santhi et al., 2006).

Potential evapotranspiration (PET) can be estimated in the model by either of the Hargreaves, Priestley-Taylor, or modified Penman-Monteith methods (Santhi et al., 2006). Sumner and Jacobs (2005) showed that the PenmanMonteith and Priestley-Taylor equations both adequately represented PET. On the other hand, Lenhart et al. (2002) and Santhi et al. (2001) used the modified Penman-Monteith method in their studies.

Surface runoff from precipitation and the hydrologic process occurring in the soil profile layer can be calculated using a modified version of the Soil Conservation Service (SCS) curve number method (Im et al., 2003; Lenhart et al., 2002; Santhi et al., 2006). Infiltration and percolation from the soil profile layer to the shallow and deep aquifers occurs as a function of antecedent soil moisture conditions. Ground water from the shallow aquifer that reaches the stream channel is lagged using a recession constant. As an alternative to the curve number method, the model provides the option to use the Green and Ampt infiltration method. Erosion and sediment yields for individual subbasins are calculated using the modified universal soil loss equation (Im et al., 2003; Lenhart et al., 2002; Santhi et al., 2006). Sediment transport capacity for a channel is estimated as a function of flow velocity where sediment is either retained or deposited in a channel segment based on the sediment load levels in the channel (Santhi et al., 2006).

\subsection{Study Area}

\subsubsection{Watershed Description}

The headwaters of Cayuga Creek are located in the town of Lewiston, New York, and from there the creek flows southward for approximately $10.5 \mathrm{mi}$ $(16.9 \mathrm{~km})$ to the city of Niagara Falls, New York, where it empties into the Little Niagara River (Figure 14.1). Two tributaries to Cayuga Creek are Bergholtz Creek and Black Creek, which combine to make up the total watershed area of $25.9 \mathrm{mi}^{2}\left(67 \mathrm{~km}^{2}\right)$. 


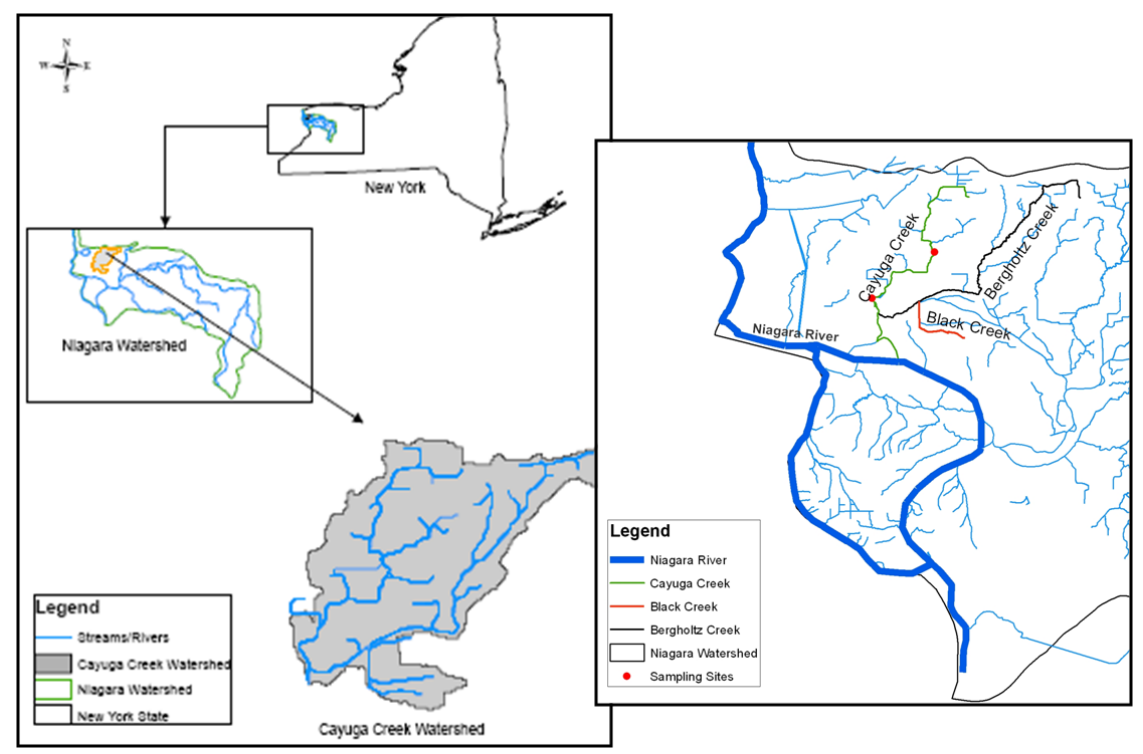

Figure 14.1 Cayuga Creek watershed.

\subsubsection{Climate}

The Niagara Region, including the metro region of Buffalo, can be generally classified as having a humid continental climate with a maritime modification effect from the Great Lakes. In accordance with the Köppen Climate Classification, the region is considered a continental climate with adequate moisture spread throughout all the months and warm summers (Dfb). The Buffalo airport has an average annual total precipitation of 38.6 in. $(98 \mathrm{~cm})$, with the driest month being February and the wettest month being August (Perrelli et al., 2005).

\subsubsection{LULC Characteristics and Changes}

Land use information as well as temporal changes in land use must be obtained to properly determine land use management practices that should be implemented (Anderson et al., 1976). 
In 1975, the LULC of the upper section of the Cayuga Creek watershed, above the Niagara Falls airbase, was characterized by agricultural lands with residential strips along major roadways.

In 2002, agricultural and open lands with mixed residential areas characterized this same LULC area. By 2002 the Niagara Falls airbase also included Niagara Falls International Airport. The town of Niagara and city of Niagara Falls, in the lower section of the watershed, experienced a development trend with increased residential and commercial land uses and a strong industrial presence remaining along the southern edge of the city of Niagara Falls.

However, the dominant LULC in the watershed is still agriculture, which is more than double any other LULC type (URS Corporation and Gomez and Sullivan, 2005).

\subsection{Methods}

\subsubsection{Sample Sites}

TSS data, flow data, and water quality data were collected at two sites in the Cayuga Creek watershed from May 2007 to August 2008, with a break during the winter months due to ice conditions (Figure 14.2). The two locations were selected to give the best spatial representation for land use and soils variability, as well as an accurate portrayal of the watershed's hydrology free of the backwater effect from the Niagara River. The sites were also selected in consultation with NCSWCD.

The downstream site (Figure 14.2) located south of the airport was a previously established sampling location used by the NCSWCD. A discharge rating curve was established for this site and limited TSS and water quality data had already been collected by NCSWCD. Furthermore, the site provided good access, a safe place to install a Hydrolab, and a relatively straight reach of the stream.

The upstream site (Figure 14.2) was not an established NCSWCD sample site but was chosen for the same reasons the downstream site was chosen. It also had good access, a safe place to install a Hydrolab, and a relatively straight reach of the stream. The main qualifier and exception from the downstream site was that this site be located upstream of the airport to capture any impact that runoff from the airport might have on water quality in the creek. 


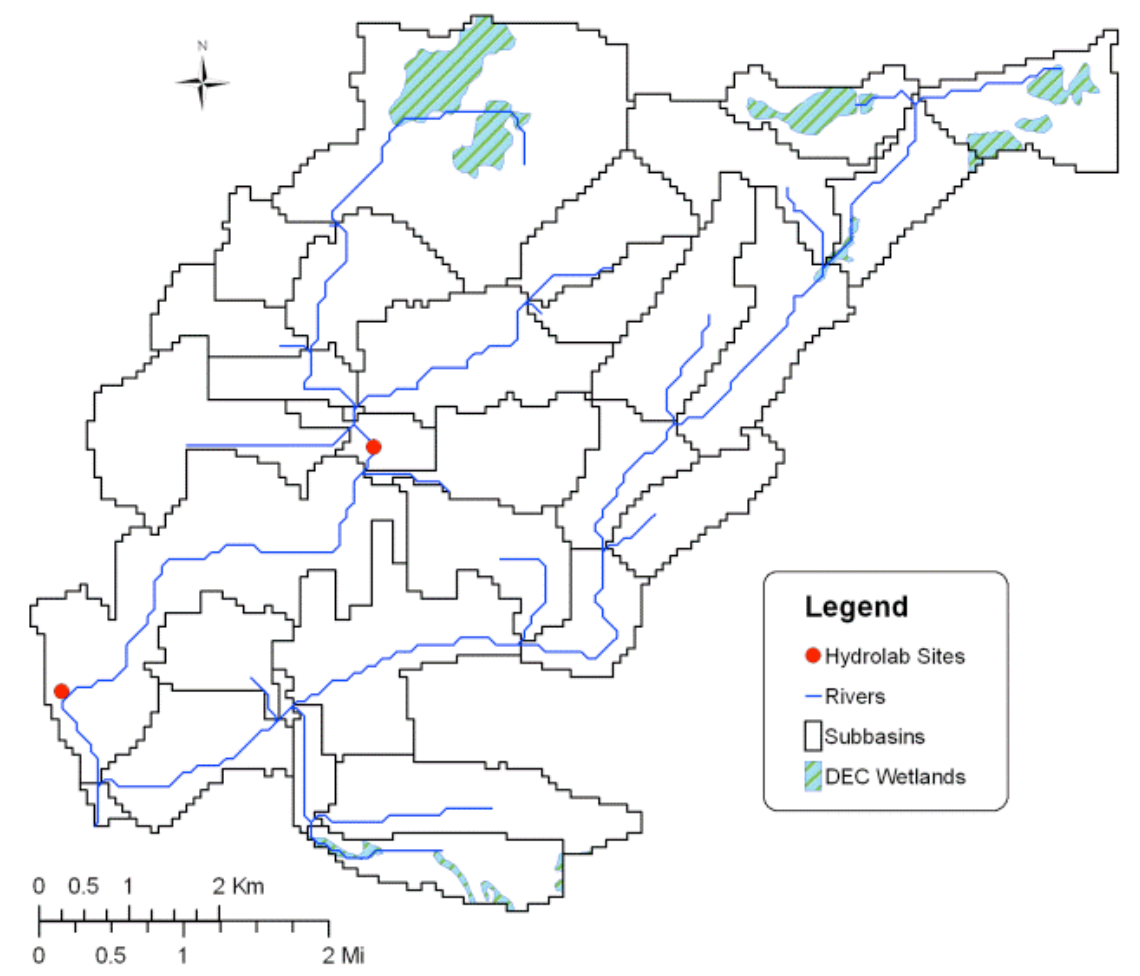

Figure 14.2 Sample site locations (dots) within the watershed. Also shown are the subbasin divisions used for the SWAT modeling and location of state-designated wetlands.

\subsubsection{Hydrolab Installation, Data Collection and Maintenance}

Hydrolab Datasonde 4a units were installed at both the upstream and downstream site in the watershed. The Hydrolabs were installed in PVC tubes to protect them against debris. Holes were drilled every 2 in. to 3 in. (approximately $5 \mathrm{~cm}$ to $7.5 \mathrm{~cm}$ ) in the PVC tube to allow water to flow freely around the unit. A cap with a lock was attached to the top of the PVC tube to prevent any tampering with the Hydrolabs. The PVC tubes were then each bolted to a pair of tractor skid plates acting as a platform to insure stability. A similar type of installation has been used in other studies (Irvine, 2003).

The primary reason for the Hydrolab installation was to record turbidity data (in NTUs), which could be used as an indicator of TSS concentration. However 
the Hydrolabs also were equipped with sensors to record a suite of other water quality parameters including dissolved oxygen (DO) percentage saturation (\% Sat), DO concentration $(\mathrm{mg} / \mathrm{L})$, conductivity $(\mathrm{mS} / \mathrm{cm}), \mathrm{pH}$, temperature $\left({ }^{\circ} \mathrm{C}\right)$, and depth $(\mathrm{m})$. Although these other water quality parameters did allow for a broader understanding of Cayuga Creek they will not be further addressed in this chapter.

Prior to installation the Hydrolabs were calibrated and set up to log at 15 min time steps for 10 days at a time even though weekly downloads were routine. This added three days would allow for some download flexibility especially when storm events occurred during scheduled download times. Weekly fieldwork consisted of downloading the data, cleaning, calibrating, and maintaining the units; then resetting the units to log. Maintenance of the units entailed changing the batteries every three to four weeks, and changing the DO membrane (DO was calibrated weekly) and calibrating $\mathrm{pH}$ every four to six weeks (cf. Irvine et al., 2005).

\subsubsection{TSS Sampling and Laboratory Procedures}

Grab samples for TSS were collected routinely once a week and also during storm events at the upstream and downstream sites during the summer through fall of 2007 and spring through fall of 2008. Samples were collected from the middle section of the stream, about $10 \mathrm{~cm}$ below the surface. Samples were kept on ice in the field and refrigerated in the Water Quality Laboratory at Buffalo State College until analysis. The TSS concentrations were determined using a standard gravimetric method with $0.45 \mu \mathrm{m}$ filters.

\subsubsection{Flow Data and Rating Curve}

Niagara County Soil and Water Conservation District personnel collected flow data at the downstream site and established a rating curve with stream depth. Measurements were taken from a bridge at this site. The stream was surveyed and a surveying rod was used to take a staff gauge reading. Staff gauge readings were recorded as part of the routine weekly sampling as well as for storm events.

At the upstream site, flow measurements were made using the area-velocity method for approximately two months as part of the weekly sampling (and storm event) procedure. Measurements were taken using a Globalwaters flow meter at the midpoint of three equally divided subsections, each approximately 
$3 \mathrm{ft}$ wide $(0.914 \mathrm{~m})$. Velocity measurements were recorded at $20 \%$ and $80 \%$ of the total depth.

\subsubsection{LULC Maps}

Historical and current land use map layers were digitized in ArcGIS9.2 for the watershed from digital air photos provided by Buffalo Niagara Riverkeeper. Land use map layers were created by editing the USGS 1970s land use map layer downloaded from the USEPA website. The air photos for the desired year were added to the data view. The land use layer was classified based on the Anderson classification scheme (Anderson, 1976; Perrelli, 2004; Perrelli et al., 2005). The land use layer transparency was set to $50 \%$ so that the air photos could be seen. In editing mode the 1970s land use polygons were cut, using the cut polygon tool from the edit toolbar, and reclassified using the Anderson classification to match the air photos interpretative land use (Anderson, 1976; Perrelli, 2004). This was done both for 2005 , the most current air photos, and for 1958 . The 1958 photos were used for historical land use because years previous to 1958 had poor coverage of the watershed. The 2005 and 1958 land use layers were integrated into the SWAT model.

\subsubsection{SWAT Model Setup}

Digital data to populate the Cayuga Creek project were extracted from the BASINS CDs distributed by the USEPA. Alternatively, the data can be downloaded from the USEPA BASINS website. We used the STATSGO data for soils and the RF3 file for stream hydrography.

The digital elevation models available from the USEPA were used with the automated watershed delineation tool in BASINS to divide the entire watershed into 35 subbasins (Figure 14.2 above). The LULC data described in the previous section was added through the BASINS utilities and the multiple land use HRU option was used with a $10 \%$ threshold.

\subsection{Results and Discussion}

\subsubsection{TSS Data and Correlation with Turbidity}

A standard regression analysis was used to assess the relationship between turbidity and TSS for both the upstream and downstream sites in Cayuga Creek. 
This regression allows for manual point samples of TSS taken weekly and during storm events to be correlated with continuous measurements of turbidity taken every $15 \mathrm{~min}$ with a Datasonde $4 \mathrm{a}$. In conducting the regression between turbidity and TSS, five turbidity measurements were averaged using the measurements taken at the time the TSS sample was collected as well as the two measurements taken $15 \mathrm{~min}$ and $30 \mathrm{~min}$ before and after the TSS sample. The five turbidity measurements were averaged to filter noise in the turbidity data. The average turbidity and TSS were then analyzed using the regression option of the Excel spreadsheet.

Numerous studies have examined the relationship between turbidity and TSS in an effort to improve our ability to evaluate watershed-scale geomorphological responses (e.g. Walling, 1977; Lewis, 1996; Sun et al., 2001; Davies-Colley and Smith, 2001).

There can be several advantages to using automated turbidity measurements as a surrogate for TSS sampling in the examination of sediment erosion and transport. These advantages include the capability of providing fine time resolution measurements (e.g. $15 \mathrm{~min}$ ) for extended periods, without having to rely on sampling teams to catch transient storm events with minimal notice (keeping teams on call to chase storms), and elimination of laboratory costs for the analysis of TSS.

Ultimately, the success of using turbidity measurements in place of TSS sampling relies on the accuracy of the TSS-turbidity rating curve. While these rating curves can be accurate, several environmental variables, including different particle size distribution, particle shape distribution, particle composition, and presence of humic acids, can produce scatter in the relationship (Walling, 1977; Lewis, 1996; Davies-Colley and Smith, 2001; Irvine et al., 2002; Pfannkuche and Schmidt, 2003). As such, Sun et al. (2001) concluded that TSS-turbidity relationships may be both site and time specific, so that a relationship is normally unique for a particular catchment and within a particular period of time.

Results of the regression between TSS and turbidity for the upstream and downstream sites are shown in Figures 14.3 and 14.4. The relationship at both sites is quite strong, with $R^{2}=0.947$ for the upstream site and $R^{2}=0.955$ for the downstream site.

Only the data for the fall of 2007 and all of the sample period 2008 were used in developing the relationships shown in Figures 14.3 and 14.4. The data from early in 2007 were not used in the regression because the three-beam type sensor at the downstream site frequently became fouled due to the high turbidity. Subsequently the three-beam sensor was switched out in favor of a selfcleaning (wiper-type) turbidity sensor and this corrected the problem. 


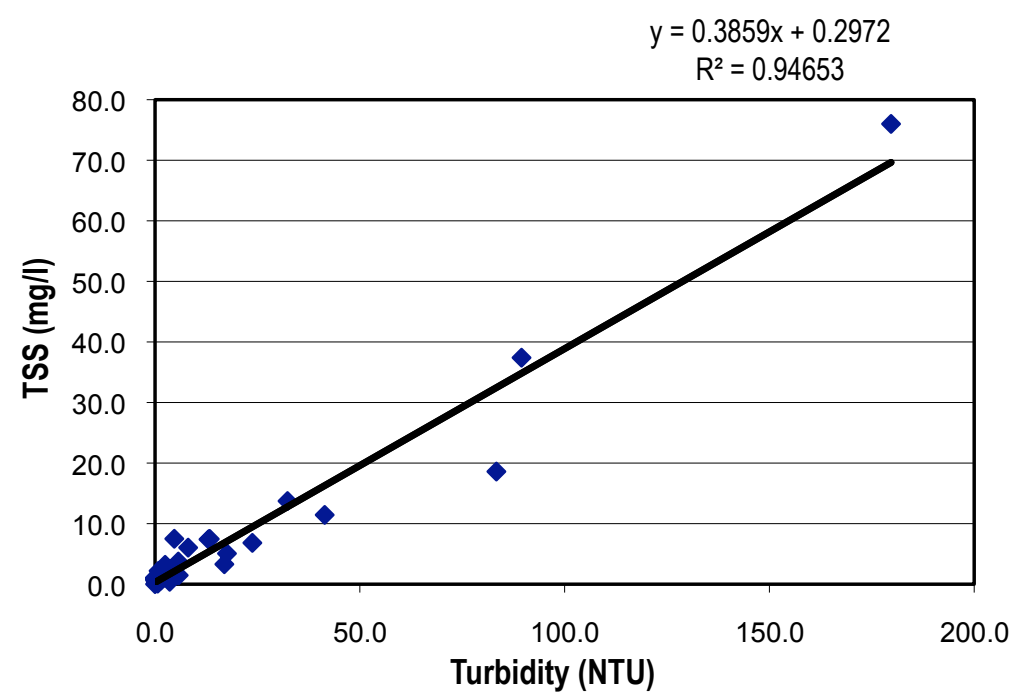

Figure 14.3 Regression analysis between TSS and turbidity, upstream site.

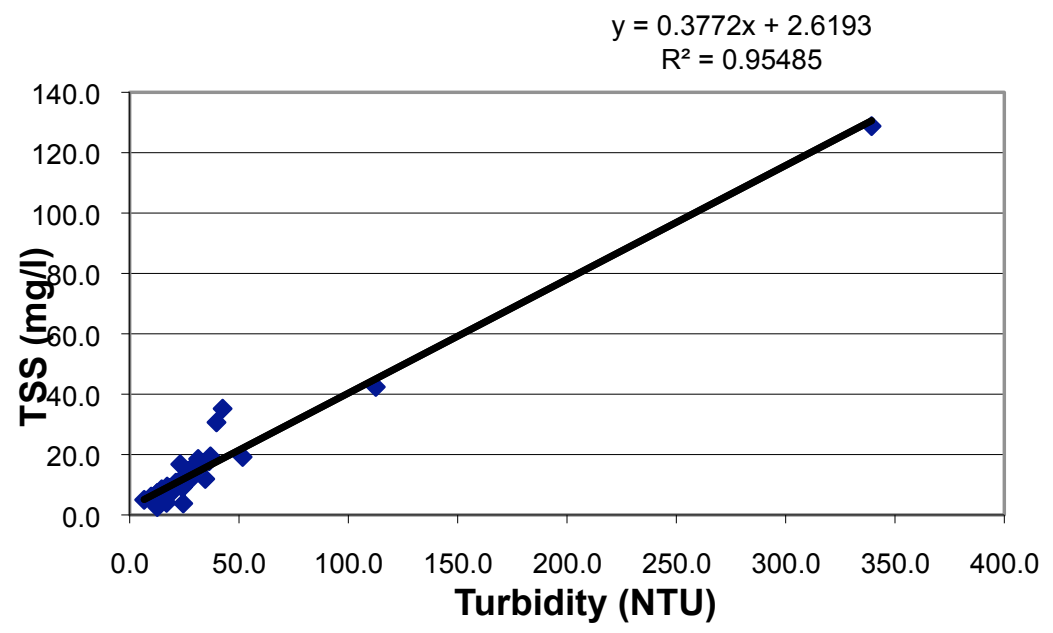

Figure 14.4 Regression analysis between TSS and turbidity, downstream site. 
A residual analysis of the raw data for both sites showed the mean of the residuals was not different from $0(\alpha=0.05)$, they were normally distributed ( $\alpha=$ 0.05 ), and a plot of the residuals versus the $x$-variable indicated relative homoscedasticity. A $\log$ normal transformation of the downstream site qualitatively showed a slightly better homoscedastic result than the raw data, but the $R^{2}$ value decreased to 0.81 and there can be bias introduced by back transformation. As a result, it was decided to use the raw data regression analysis in this study.

The equation for the best-fit line (shown in Figures 14.3 and 14.4) was used to calculate continuous TSS values. The continuous TSS values were then used to calibrate both the upstream and downstream sites in the SWAT model. The base level of TSS at the downstream site was on average about $10 \mathrm{mg} / \mathrm{L}$ while the base level of TSS at the upstream site was on average around $5 \mathrm{mg} / \mathrm{L}$. The base level concentrations in Cayuga Creek are comparable to those determined for other local rivers (e.g. Cazenovia Creek, Buffalo River; Irvine et al., 2003). However, the upper end of the TSS concentration range determined in this study only represents moderate-sized storm events and as a result the upper end is relatively low. Large storm events in the Buffalo River watershed can have TSS levels that approach $1000 \mathrm{mg} / \mathrm{L}$ (Irvine et al., 2003; Inamdar and Naumov, 2006).

\subsubsection{LULC Maps}

In comparing the 1958 LULC map to the 2005 LULC map there was more extensive agriculture and much less urban residential land use outside the city of Niagara Falls in 1958. Table 14.1 summarizes this shift in land use.

Table 14.1 Summary of LULC, 1958 and 2005.

\begin{tabular}{lccc}
\hline \multicolumn{1}{c}{ Land Use } & 1958 \% of Area & 2005 \% of Area & Change in \% Area \\
\hline Range-Brush & 1.68 & 4.2 & 2.52 \\
Water & 0.51 & 1.59 & 1.08 \\
Wetlands-Forested & 0.23 & 3.91 & 3.68 \\
Wetlands-Non-Forested & 0.11 & 0.03 & -0.08 \\
Commercial & 4.22 & 10.13 & 5.91 \\
Forest-Deciduous & 6.33 & 10.83 & 4.49 \\
Agricultural & 71.47 & 40.91 & -30.56 \\
Industrial & 0.89 & 0.83 & -0.06 \\
Transportation & 7.54 & 6.86 & -0.68 \\
Residential & 7.0 & 20.7 & 13.69 \\
\hline
\end{tabular}


The GIS land use maps are not shown because the land use polygons are difficult to differentiate when not reproduced in color. This change in land use between 1958 and 2005 reflects historical information provided by URS Corporation and Gomez and Sullivan (2005) and the Niagara County Department of Planning, Development and Tourism.

\subsubsection{Model Flow Calibration}

The model was calibrated for the period 04/01/08-08/14/08. Flow data were collected for the last eight weeks of the calibration period at the downstream site and for the last six weeks of the calibration period at the upstream site. The results of the recorded flow data are represented as point samples in the downstream (Figure 14.5) and upstream (Figure 14.6) calibrations. It should be noted that the measurements represent single points in time (for dry weather periods), or the average of several measurements through the day (for storm events), rather than a true daily mean (as represented by SWAT output). Normally, regression $R^{2}$ values and Nash Sutcliffe model efficiency coefficients are used to assess model predictions, although no absolute criteria for judging model performance have been established (Gassman et al., 2007). However, detailed flow data collection was outside the mandate of this study, and because of the limited observed data collected a statistical assessment of model performance was not warranted. Here we simply rely upon a qualitative visual assessment.

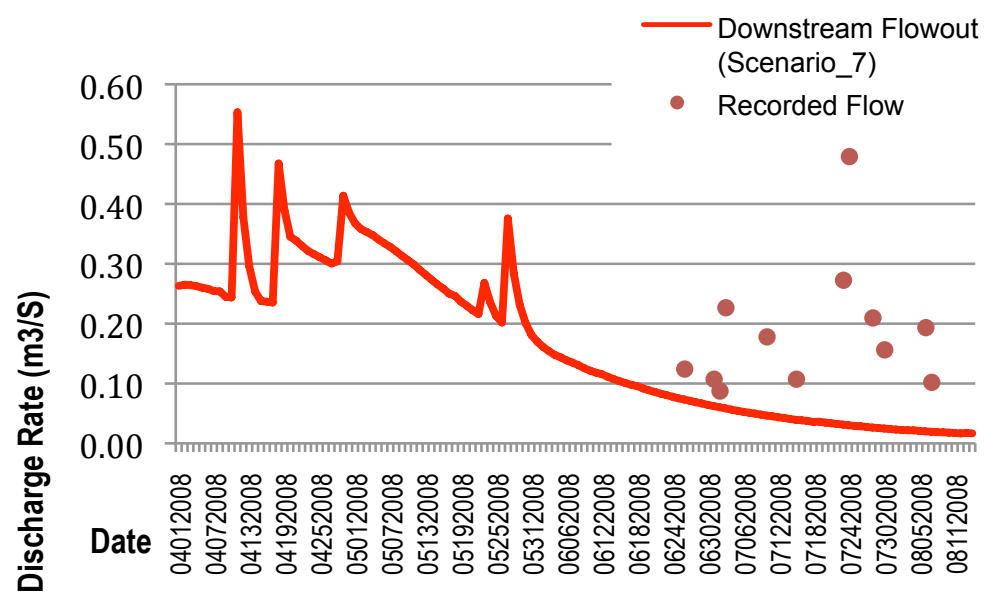

Figure 14.5 Downstream flow calibration. 


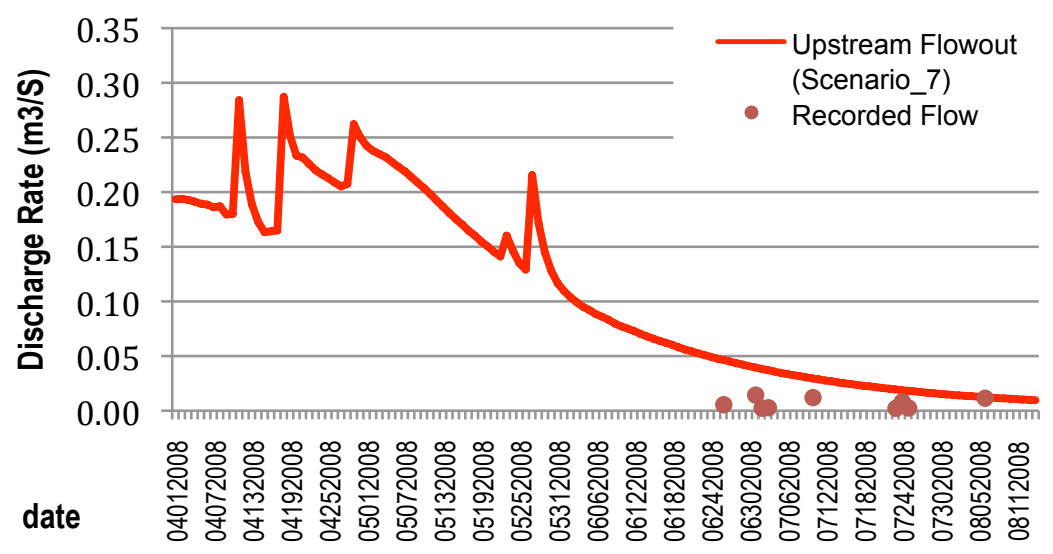

Figure 14.6 Upstream flow calibration.

The preferred scenario for both sites included adjustments to the default values for the parameters CN2 (SCS curve number), GWRevap (groundwater evaporation coefficient), Esco (soil evaporation compensation factor), Spcon (linear factor for channel sediment routing), and Spexp (exponential factor for sediment routing) (Table 14.2). The adjustments were guided by results for a SWAT application in the nearby Buffalo River watershed (Inamdar, 2004) that had long term flow records available from the USGS. Results of the preferred scenario were moderately accurate during dry weather, off by $0.2 \mathrm{~m}^{3} / \mathrm{s}$ or $0.3 \mathrm{~m}^{3} / \mathrm{s}$ at the downstream site, and were a good representation of flow with a slight over prediction at the upstream site. The greater variability of measured flow at the downstream site may reflect pumping operations from an upstream quarry, but this remains to be confirmed. Model results were less accurate for storm events. Part of the reason for poorer accuracy for storm events is the short sequence of recorded flow data taken during the summer months. The spatial variability of weather data could also play a role in the modeling error of flow. When the model was setup all the 35 subbasins were assigned the same weather data from the closest National Weather Service gauge (Lockport) which is $23 \mathrm{~km}$ northeast of the watershed. Perrelli et al. (2005) reported that spatial variability of rainfall had a significant effect on model results in the Buffalo River watershed. This finding also is consistent with reports from other studies (e.g. Engelmann et al., 2002; Larose et al., 2007; Gassman et al., 2007). 
Table 14.2 Calibration parameter values for Cayuga Creek as compared to the literature.

\begin{tabular}{lllcc}
\hline \multicolumn{1}{c}{ Variable } & Model Process & Description & $\begin{array}{c}\text { Model Range (suggested } \\
\text { by Santhi et al., 2001; } \\
\text { 2006) }\end{array}$ & $\begin{array}{c}\text { Preferred Sce- } \\
\text { nario, Cayuga } \\
\text { Creek }\end{array}$ \\
\hline $\begin{array}{l}\text { CN2 } \\
\text { REVAPC } \\
\text { (GWREVAP) } \\
\text { ESCO }\end{array}$ & $\begin{array}{l}\text { Surface runoff } \\
\text { Baseflow }\end{array}$ & $\begin{array}{l}\text { Curve number } \\
\text { Ground water revap } \\
\text { coefficient } \\
\text { Soil evaporation }\end{array}$ & $\begin{array}{c} \pm 10 \% \text { of default values } \\
0.00-1.00\end{array}$ & $-8 \%$ \\
EPCO & Baseflow & $\begin{array}{l}\text { Sompensation factor } \\
\text { comp } \\
\text { Plant uptake com- } \\
\text { pensation factor } \\
\text { Cover or manage- }\end{array}$ & $0.00-1.00$ & 0.4 \\
ment factor & $0.00-1.00$ & 0.8 \\
SPCON & Sediment & $\begin{array}{l}\text { Linear factor for } \\
\text { channel sediment } \\
\text { routing } \\
\text { Exponential factor } \\
\text { for sediment rout- } \\
\text { ing }\end{array}$ & $0.0001-0.01$ & 0.0001 \\
\hline
\end{tabular}

Median flow was estimated for lower Cayuga Creek by URS Corporation and Gomez and Sullivan (2005) using a multiple regression approach based on drainage area, precipitation data, and observed daily mean flow from the USGS gauge stations located on unregulated streams in the Niagara Region. Median flow for July and August in this approach was estimated as $0.25 \mathrm{~m}^{3} / \mathrm{s}$ to 0.29 $\mathrm{m}^{3} / \mathrm{s}$ for Cayuga Creek which certainly is in the range of flows estimated for the July and August calibration period.

\subsubsection{Model TSS Calibration}

Typically, TSS is more difficult to model than flow because of the combined complexities of flow and erosion processes (cf. Gassman et al., 2007). TSS calibration is contingent upon the accurate calibration of flow data because there is a direct relationship between the level of flow and the level of suspended sediment in a stream reach. Furthermore, Garen and Moore (2005) note that the curve number approach is reasonable in estimating flood hydrology but has its limitations when used in estimating erosion because it does not distinguish well between flow paths within the watershed.

The preferred scenario provided a good representation of the overall levels of TSS for both the downstream (Figure 14.7) and upstream (Figure 14.8) sediment concentrations with the exception of the peaks (e.g. 04/11/08 and 04/17/08), which corresponded to elevated levels in flow. Furthermore, the 
preferred scenario had an overall tendency to moderately under-predict TSS levels when compared to recorded TSS. This can be partly explained by the modeled flow (Figures 14.5 and 14.6) under-predicting the recorded base level of flow during the summer months, which is then carried through when calibrating TSS.

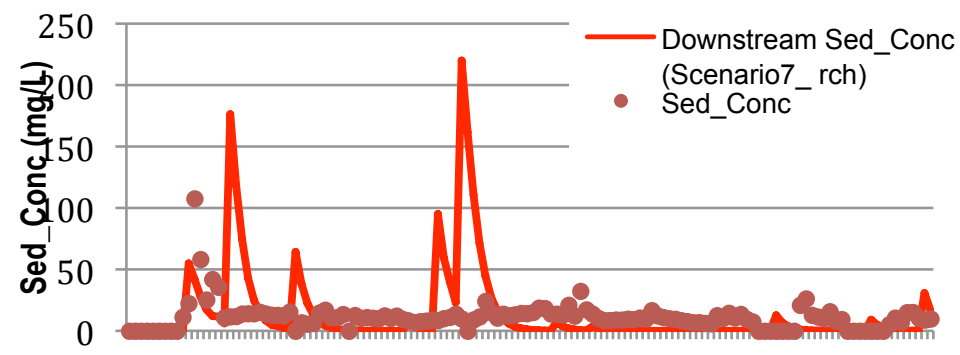

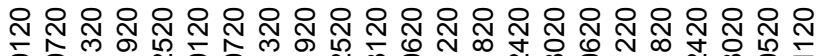

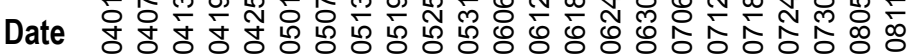

Figure 14.7 Downstream sediment concentration calibration.

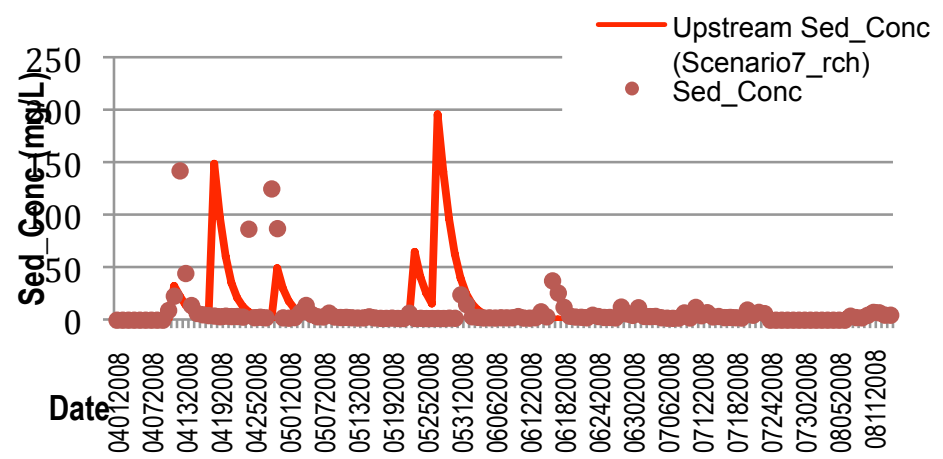

Figure 14.8 Upstream sediment concentration calibration.

\subsubsection{Model Flow Validation}

The model was validated for the preferred scenario for the period $05 / 04 / 07$ $11 / 28 / 07$. A relatively good data set was collected for flow at the downstream site (Figure 14.9) by the NCSWCD but no flow data were collected to validate the model at the upstream site. Model validation for the downstream site is 
quite good with minor over-prediction during the wet spring and fall months and a slight under-prediction during the dry summer months, which is consistent with calibration results.

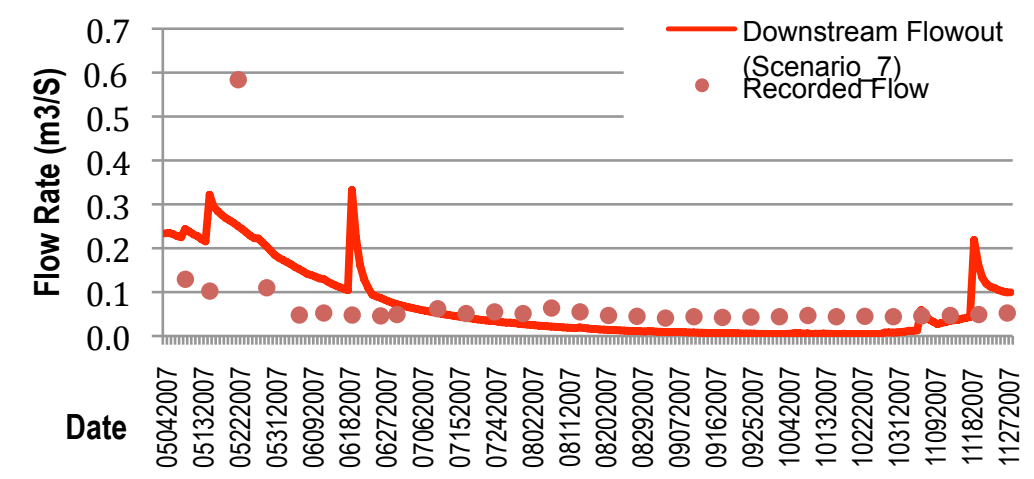

Figure 14.9 Downstream flow validation.

\subsubsection{Model TSS Validation}

Model validation for TSS was done for the same scenario and time period as for flow. When comparing recorded TSS data to the preferred scenario for both the downstream (Figure 14.10) and the upstream (Figure 14.11) sites the validation results are similar to those of the calibration. There is a relatively good fit for TSS during dry weather with fluctuations during wetter months (e.g. May), which can be most likely explained by lack of flow data allowing for a good calibration.

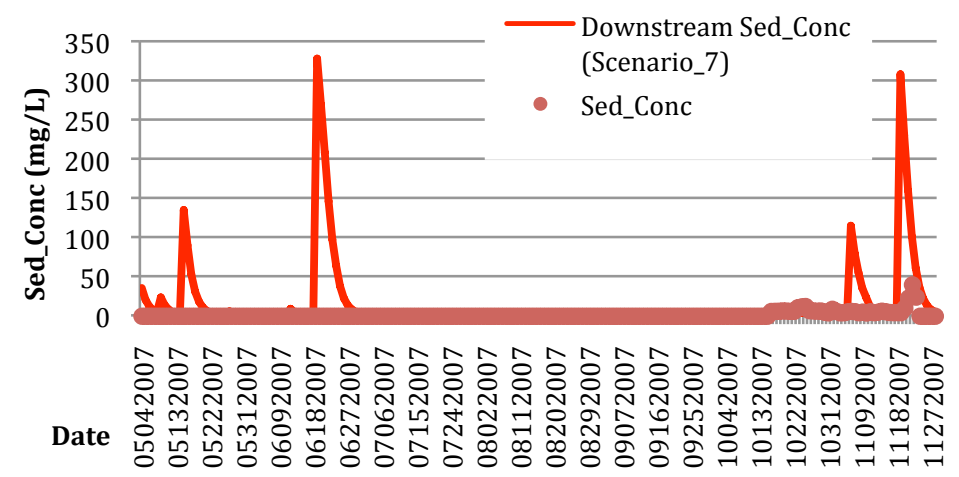

Figure 14.10 Downstream sediment concentration validation. 


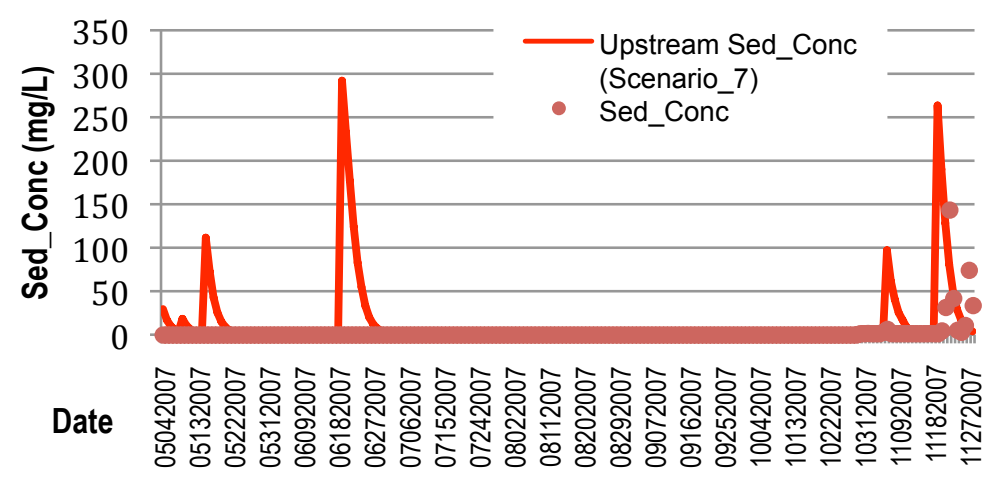

Figure 14.11 Upstream sediment concentration validation.

\subsubsection{Accuracy of Using Default Parameters}

In their review of $>250$ peer reviewed publications related to SWAT applications, Gassman et al. (2007) noted that the majority of these studies provided some type of graphical or statistical hydrologic calibration, with somewhat fewer providing validation runs. Nearly half of the 250 studies included analysis of one or more pollutants but the extent of calibration and validation was less than for those studies focusing strictly on hydrology.

As noted above, however, a number of researchers have indicated that SWAT was developed, in particular, to help make management decisions for large, ungauged watersheds (e.g. Santhi et al., 2006; Gassman et al., 2007). To explore the accuracy of the default parameters in predicting flow and sediment concentration in Cayuga Creek, the results for the calibration period 04/01/0808/14/08 for the downstream site are shown in Figures 14.12 and 14.13.

The flow estimates for the downstream site using the default parameters (Figure 14.12) are reasonable and probably would be accurate enough for planning level studies. A similar conclusion could be drawn for the upstream site (not shown, in the interest of space). The suspended sediment concentration estimates (Figure 14.13), however, exhibit more variability and a generally poorer fit than the calibrated model results shown in Figure 14.8 above. In this study, it appears that the default parameters capture the runoff processes reasonably well, but the same is not true for the erosion processes. 
One solution to address this problem for ungauged watersheds may be to use parameter values derived from nearby gauged watersheds as a guide (e.g. Heuvelmans et al., 2004).

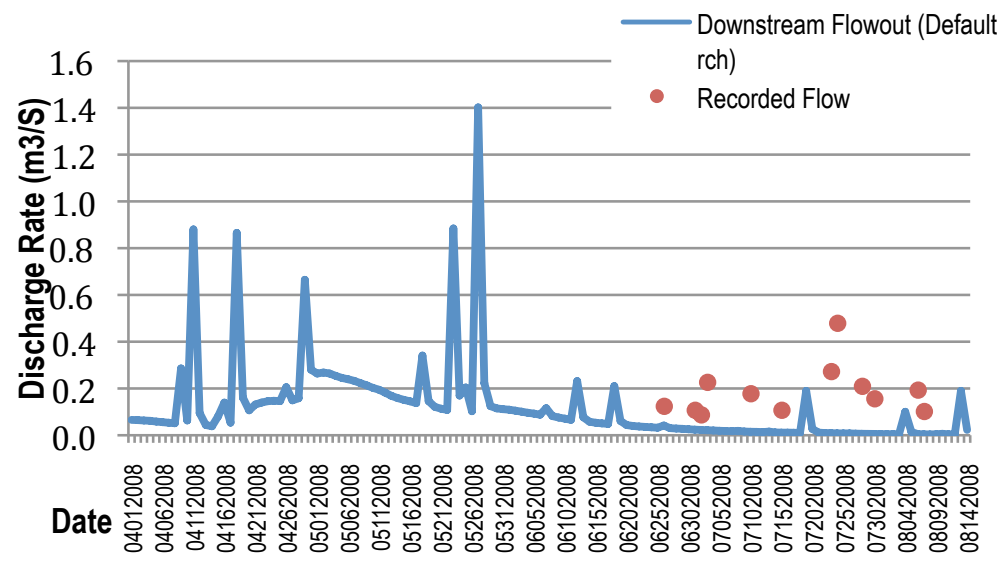

Figure 14.12 Downstream flow estimate with default parameter values.

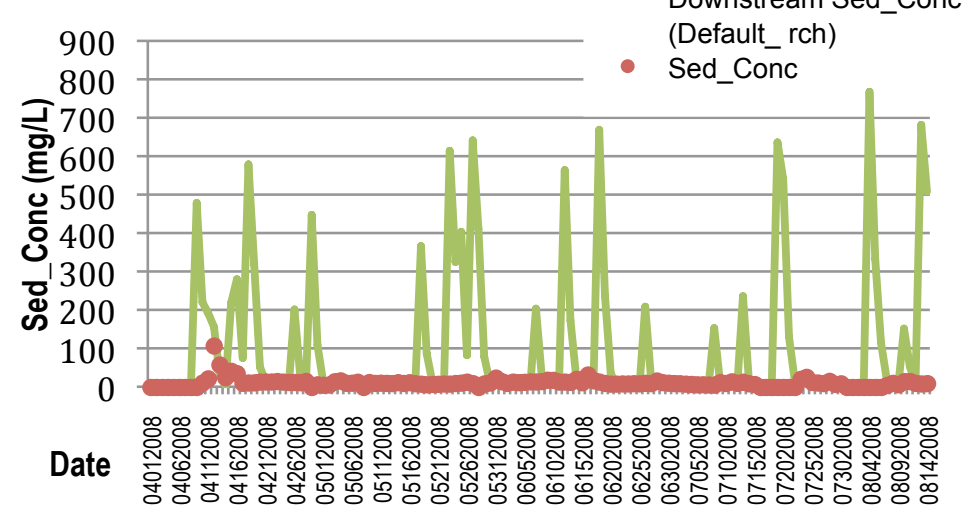

Figure 14.13 Downstream sediment concentration estimate with default parameter values.

\subsubsection{Model Runs with 1958 and 2005 Land Use}

The model was run with the 1958 and 2005 LULC and meteorology from October and November, 2007, and April through August, 2008, to predict how 
change in land use might affect flow and TSS conditions. When comparing monthly average flow at both the downstream and upstream sites for the 1958 LULC to monthly average flow at both the downstream and upstream sites for the 2005 LULC, the 1958 flows generally were estimated to be lower. As the land use increasingly shifted from agriculture to residential and urban land (Table 14.1 above) a general increase in flow was estimated to occur. This shows how increased impermeable surface might affect the flow conditions in the watershed.

When comparing the sediment concentration at the downstream and the upstream sites for the 1958 LULC to the sediment concentration at the downstream and the upstream sites for the 2005 LULC, the TSS levels in 2005 generally were lower (Table 14.3). This change is mostly likely due to greater available sediment from surface runoff from agriculture when using the 1958 LULC.

Table 14.3 Monthly average TSS concentrations.

\begin{tabular}{ccccc}
\hline \multicolumn{5}{c}{ Monthly Average Sediment Concentrations (mg/L) } \\
\hline Monthly & 1958 LULC & 1958 LULC & 2005 LULC & 2005 LULC \\
Oct-07 & Up & Down & Up & Down \\
Nov-07 & 0.53 & 0.93 & 0.33 & 0.94 \\
Apr-08 & 55 & 72 & 41 & 49 \\
May-08 & 26 & 42 & 19 & 25 \\
Jun-08 & 38 & 55 & 23 & 29 \\
Jul-08 & 4.8 & 9.2 & 2.1 & 3.0 \\
Aug-08 & 0.04 & 7.9 & 0.02 & 0.91 \\
\hline
\end{tabular}

\subsection{Conclusions}

The BASINS SWAT model was developed as a tool to aid state and local officials in their decision making for the Cayuga Creek watershed by assisting in the assessment of water quality issues associated with sediment erosion and surface runoff, with a specific focus on the impact of land use change. There was a $13 \%$ increase in urban area between 1958 and 2005 and a 30\% decrease in agricultural land use. Agricultural land use has become more fragmented since 1958. Even by 1958 there was a relatively small amount of forest land.

Using the least squares regression approach a strong relationship was found between turbidity and TSS concentration ( $R^{2}$ of 0.95 at both sites). This relationship enabled us to estimate continuous TSS concentration from turbidity data to assist with model calibration. SWAT model results show that monthly 
mean TSS concentrations in the summer through fall might be in the range $0.1 \mathrm{mg} / \mathrm{L}$ to $75 \mathrm{mg} / \mathrm{L}$, with concentrations being slightly higher at the downstream site than the upstream site. The model results also show that sediment concentrations might be slightly lower in 2005 than 1958. This probably is related to land use change, specifically the decrease in agricultural land and increase in brush land. At this point, the impact of BMP implementation between 1958 and 2005 has not been considered in the model. The SWAT model potentially is useful at the watershed scale to identify the magnitude of BMP impact at a planning level. It certainly is possible to pick up general level trends on a gross scale (e.g. due to land use change). However, the land use change represented spatially widespread impacts throughout the watershed and small scale BMP implementation might not be seen by the model at the watershed scale. Instrumentation of a couple of subbasins to provide more detailed information on system response would lead to improved understanding of parameter sensitivity and ultimately result in more certain model calibration and application.

Because of minimal measured data it was not possible to quantitatively assess the model accuracy. Additional flow and suspended sediment data should be collected for more rigorous model calibration and validation in the future and at least one rain gauge site should be established within the watershed to produce more accurate model results. It is particularly important to focus future sampling and modeling efforts on more accurately characterizing the moderate to larger storm events in each year since these have the potential to produce most of the load to be controlled by a TMDL. Model estimates of flow within the watershed derived from default parameter values were accurate to a planning level scale, while sediment concentration estimates were less accurate. Caution must be used if SWAT is to be applied for study in an ungauged watershed and if possible parameter values derived from nearby gauged watersheds should be used as a guide.

\section{Acknowledgments}

Thanks to Kerry Kleinfelder and Jess Bakert for outstanding help in collecting and analyzing TSS samples and maintaining the Hydrolabs. Funding was provided by the U.S. Army Corps of Engineers, Buffalo District, under the authority of Section 516(e) of the Water Resources Development Act, 1996. Views expressed in this chapter are solely the responsibility of the authors. 


\section{References}

Anderson, J.R., Hardy, E.E., Roach, J.T., and Witmer, R.E. 1976. A Land Use and Land Cover Classification System for Use with Remote Sensor Data. Geological Survey Professional Paper 964, US Government Printing Office, Washington.

Arnold, J.G., Srinivasan, R., Muttiah, R.S., and Williams, J.R. 1998. Large Area Hydrologic Modeling and Assessment Part1: Model Development. Journal of the American Water Resource Association, 31(1): 73-89.

Bevan, K.J. 2004. Rainfall runoff modeling: The primer. New York: John Wiley.

Bogen, J., Walling, D.E., and Day, T.J., 1992. Erosion and Sediment Transport Monitoring Programmes in River Basins. Proceedings of the Oslo Symposium. IAHS Publ. no. 210.

Bracmort, K.S., Arabi, M., Frankenberger, J.R., Engel, B.A., and Arnold, J.G. 2006. Modeling Long term Water Quality Impact of Structural BMPs. American Society of Agriculture and Biological Engineers 49(2): 367-374.

Davies-Colley, R.J. and Smith, D.G. 2001. Turbidity, suspended sediment, and water clarity: A review. Journal of the American Water Resources Association. 37(5):10851101.

Di Luzio, M., Srinivasan, R., and Arnold, J.G. 2002. Integration of watershed tools and SWAT model into BASINS. Journal of the American Water Resources Association. 38(4): 1127-1141.

Engelmann, C.J.K., Ward, A.D., Christy, A.D., and Bair, E.S. 2002. Application of the BASINS database and NPSM model on a small Ohio watershed. Journal of the American Water Resources Association. 38(1): 289-300.

Flugel, W.A. 1995. Hydrological response units (HRUs) to preserve basin heterogeneity in hydrological modeling using PRMS/MMS - case study in the Brol basin, Germany. In. Modeling and management of sustainable basin-scale water resource systems. IAHS Publ. No. 231.

Garen, D.C. and Moore, D.S. 2005. Curve number hydrology in water quality modeling: Uses, abuses, and future directions. Journal of the American Water Resources Association. 41(2): 377-388.

Gassman, P.W., Reyes, M.R., Green, C.H., and Arnold, J.G. 2007. The Soil and Water Assessment Tool: Historical development, applications, and future research directions. Transactions of the ASABE. 50(4): 1211-1250.

Grunwald, S. and Qi, C. 2006. GIS-based water quality modeling in the Sandusky Watershed, Ohio, USA. Journal of the American Water Resources Association. 42(4): 957973.

Heuvelmans, G., Muys, B., and Feyen, J. 2004. Analysis of the spatial variation in the parameters of the SWAT model with application in Flanders, Northern Belgium. Hydrology and Earth System Sciences. 8(5): 931-939.

Im, S., Brannan, K., Mostaghimi, S., and Cho, J. 2003. A comparison of SWAT and HSPF Models for Simulating Hydrologic and Water Quality Responses from an Urbanizing Watershed. ASAE Paper No. 032175. St. Joseph, Michigan: ASAE.

Inamdar, S. 2004. Assessment of modeling tools and data needs for developing the sediment portion of the TMDL plan for a mixed land use watershed. Report for the Great Lakes Commission. 
Inamdar, S. and Naumov, A. 2006. Assessment of sediment yields for a mixed land use Great Lakes watershed: Lessons from field measurements and modeling. J. Great Lakes Res. 32: 471-488.

Irvine, K.N. 2003. Continuous Measurement of Conventional Parameters in the Allegheny River and Oil Creek, PA, in Support of the Oil City CSO Long Term Control Plan. Report to the City of Oil City, PA.

Irvine, K.N., McCorkhill, G., and Caruso, J. 2005. Continuous monitoring of conventional parameters to assess receiving water quality in support of combined sewer overflow abatement plans. Water Environment Research. 77(5):543-552.

Irvine, K.N., Somoyge, E.L., and Pettibone, G.W. 2002. Turbidity, suspended solids, and bacteria relationships in the Buffalo River watershed. Middle States Geographer. $35: 42-51$.

Larose, M., Heathman, G.C., Norton, L.D., and Engel, B. 2007. Hydrologic and atrazine simulation of the Cedar Creek Watershed using the SWAT model. J. Environ. Qual. 36: 521-531.

Lenhart, T., Eckhardt, K., Fohrer, N., and Frede, H.-G. 2002. Comparison of Two Different Approaches of Sensitivity Analysis. Physics and Chemistry of the Earth 27(2002): 645-654.

Lewis, J. 1996. Turbidity-controlled suspended sediment sampling for runoff-event load estimation. Water Resources Research. 32(7): 2299-2310

Neitsch, S.L., Arnold, J.G., Kiniry, J.R., and Williams, J.R. 2001. Soil and Water Assessment Tool User's Manual: Version 2000.

Niagara County Water Quality Committee, 1992. Non-point Source Pollution Abatement Strategy for Niagara County, New York. Report to the New York State Soil and Water Conservation Committee.

Perrelli, M., K. Irvine and T.S. Lee. 2005. "Calibration of BASINS HSP-F in Support of a Watershed Approach to CSO Long Term Control Planning." Journal of Water Management Modeling R223-20. doi: 10.14796/JWMM.R223-20.

Perrelli, M. 2004. Buffalo River Watershed Sediment Modeling: 2002 Land Use Update. Department of Geography and Planning Buffalo State College.

Pfannkuche, J. and Schmidt, A. 2003. Determination of suspended particulate matter concentration from turbidity measurements: Particle size effects and calibration procedures. Hydrological Processes. 17: 1951-1963.

Santhi, C., Arnold, J.G., Williams, J.R., Dugas, W.A., Srinivasan, R., and Hauck, L.M. 2001. Validation of SWAT Model on a Large River Basin with Point and Nonpoint Source. Journal of the American Water Resource Association 37(5): 1169-1188.

Santhi, C., Srinivasan, R., Arnold, J.G., and Williams, J.R. 2006. A Modeling Approach to Evaluate the Impacts of Water Quality Management Plans Implemented in a Watershed in Texas. Environmental Modeling \& Software, 21 (2006): 1141-1157.

Sumner, D. M. and Jacobs, J.M. 2005. Utility of Penman-Monteith, Priestley-Taylor, reference evapotranspiration, and pan evaporation methods to estimate pasture evapotranspiration. Journal of Hydrology 308(2005): 81-104.

Sun, H., Cornish, P.S., and Daniell, T.M. 2001. Turbidity-based erosion estimation in a catchment in South Australia. Journal of Hydrology. 253: 227-238. 
USEPA. 2001. Better Assessment Science Integrating point and Nonpoint Sources BASINS Version 3 User's Manual. EPA-823-B-01-001.

URS Corporation and Gomez and Sullivan, 2005. Upper Niagara River tributary Backwater Study, Report for the New York Power Authority, Niagara Power Project FERC Application No. 2216.

Walling, D.E. 1977. Assessing the Accuracy of Suspended Sediment Rating curves for a Small Basin. Water Resource Research. 13(3): 531-538. 